\title{
Knowledge, Attitude and Practice of ICT Use in Teaching and Learning: In the Context of Bangladeshi Tertiary Education
}

\author{
Arifa Rahman ${ }^{1}$, F. M. Arifur Rahman ${ }^{2}$ \\ ${ }^{1}$ Green University of Bangladesh, Center of Excellence for Teaching and Learning, Rokeya Sharani Road, Agargaon-1207, Bangladesh \\ ${ }^{2}$ Green University of Bangladesh, Center for Research Innovation and Transformation, Rokeya Sharani Road, Agargaon-1207, Bangladesh
}

\begin{abstract}
This study aimed at investigating Knowledge, Attitude \& Practice (KAP) level of using ICT tools and services by the teachers and students of universities in Dhaka Metropolitan City. A total of 523 respondents from 31 universities were surveyed using questionnaire method in 2015. Univariate frequency distribution method, bivariate crosstabs method and testing methods for qualitative data were used for data analyses. The study found that, in spite of a higher level of knowledge regarding different tools \& services of ICT in teaching \& learning, the practices of those were not satisfactory. Also, there were significant associations between $K, A \& P$ of different ICT tools and services, though for most of them the associations were not so strong. Finally, it is also found that, occupation, university type and ownership of a PC makes significant differences for knowledge and practice level in using ICT in teaching \& learning.
\end{abstract}

Keywords: ICT, Tertiary education, KAP, Bangladesh

\section{Introduction}

The world is rapidly evolving with ICT. The use of ICT at different aspects of life makes it easy and comfortable. The use of ICT in education especially in higher education can play a huge role in effectively and quickly transferring and receiving knowledge and in making education more universal \& rich. Higher education is undergoing an example by integrating technology. The past two decades are assumed to have revolutionized and revitalized the higher education sector tremendously due to ICT based teaching-learning (Cubukcuoglu, 2013)[1]. Education technologist Bates said in 2004 that universities must either ,transform or die ${ }^{\text {ee }}$ in coping with technological progress. Universities can integrate ICT in their teaching-learning activities, administration, maintaining and managing resources whereas only limited academic usages of ICT during teaching and learning are maintained. Electronic information is attractive and more important for the academic community as university academics require large scale and current information (Goharinezhad, Faraji, \& Jameie, December 2012)[2].

Moreover, the uses of ICT in classrooms are considered to ensure quality teaching (Rahman \& Akter, February 2015)[3]. ICT uses in education are related to attitude and motivation, confidence in using ICT and experience (Cubukcuoglu, 2013)[1]. Drent and Meelissen (2008) discovered that having strong ICT competence is an important factor in using ICT in teaching. A study revealed that teacherse attitudes, knowledge and skills were the biggest enablers in integrating technology where teachers express high desire to integrate ICT in education (Bingimlas, 2009) [4]. The study about Knowledge, Attitude and Practice (KAP) of ICT among the students and teachers of tertiary education and its impact on their learning can provide real facts about the ICT integration which might impact ICT based teaching-learning process. Consequently, the purpose of this study is to investigate Knowledge, Attitude \& Practice (KAP) level of using ICT tools and services by the teachers and students of the universities in Dhaka metropolitan city.

\section{Literature Review}

Education and technology have become progressively more basic requirements for the standard of living in the twentyfirst century. Innovations in technology have an impact on education and pedagogy. Many developed and developing countries have been encouraging the use of new technologies in different subjects as teaching tools over the last three decades (Cubukcuoglu, 2013)[1].

The study on "ICT-Periodism in the Classroom: Lesson Learnt from English in Action" has illustrated the factors affecting the use of ICT in the large scale which is mainly focused on the use of audio in EIA classrooms during different quarters of the year. Findings shows that different nature and the pressure of the contents during different quarters of the years and the examination focused education system are the key factors that affect the use of ICT in English classes at the primary level. Digitalization of teacher professional development (TPD) materials and the use of ICT in classrooms are being considered as the means of ensuring quality teaching. There is evidence that highly motivated teachers are more likely to engage in professional development and implement innovative programmes to increase student learning. The study also found that the use of audio increases and a number of factors are related for that like attitude (Rahman \& Akter, February 2015) [3].

It was found from a study that teachers have positive attitudes towards the use of ICT as a pedagogical tool though integrating ICT use in teaching was not effectively done as few teachers used ICT as a pedagogical tool; specially email, online assignments due to their lack of attention towards

\section{Volume 4 Issue 12, December 2015}




\section{International Journal of Science and Research (IJSR) \\ ISSN (Online): 2319-7064}

Index Copernicus Value (2013): 6.14 | Impact Factor (2014): 5.611

using ICT. Low familiarity with ICT use as a pedagogical tool, teachers ${ }^{\text {ee }}$ willingness, confidence, motivation, feeling, thinking, belief and the lack of actual practices were the reasons. The study recommended to investigate this important concept- ,ICT as a pedagogical tool ${ }^{\text {ee }}$ by considering those facts (Ndibalema, 2014) [5]. Teachers pointed out on a study titled "Teacher beliefs and technology integration practices: A critical relationship" that the strongest barriers for using technology were their existing attitudes and beliefs toward technology, current levels of knowledge and skills. The study also recommended for studying further on those issues (Ertmer, OttenbreitLeftwich, Sadik, Sendurur, \& Sendurur, 2012) [6]. A study on "Factors enabling the use of technology in subject teaching" disclosed that to create a technology friendly learning environment, addressing the needs of teachers in using technology in teaching and learning is essential. The enabling factors would help teachers to be motivated and enthusiastic users of ICT in education (Cubukcuoglu, 2013) [1].

The research on Student-Teachers ${ }^{e e}$ Competence and Attitude towards Information and Communication Technology: A Case Study in a Nigerian University examined empirically student-teachers ${ }^{\text {ee }}$ competence and attitude towards information and communication technology on 382 studentteachers (181 males and 201 females) from the Faculty of Education, University of Ilorin, Nigeria. Findings of the study revealed that majority of the student-teachers have positive attitude towards the use of ICT and they are competent in the use of few basic ICT tools and no significant difference was established between male and female student-teachers ${ }^{\text {ee }}$ attitudes and use of ICT. However, the student $\&$ teachers mentioned their lacking of necessary competence in the full integration of ICT in the curriculum which underlines the need of ICT knowledge of teacher and students in universities in developing nations (Yusuf \& Balogun, 2011) [7].

A cross-sectional study was conducted through a selfadministrated questionnaire in 2011 with a purpose to measure Knowledge, Attitude and Practice (KAP) of 150 faculty members on Integrated Digital Library (IDL) in Tehran University of Medical Sciences. The survey found that Integrated Digital Library (IDL) played precious function to amplify Knowledge, Attitudes, and Practice (KAP) of faculty members. Libraries were also progressively more involved in integrating ICT as the demand of ICT increased recently for academic and research community (Goharinezhad, Faraji, \& Jameie, December 2012) [2].

\section{Research Objectives}

The general objective of the study is to investigate the situation of KAP of ICT in tertiary teaching \& learning and to analyze the associations between themselves and with other background factors. So the specific objectives can be stated as below-

- To explore the present situation of KAP of ICT among teachers and students of tertiary institutions of Dhaka city

- To identify if there are any associations between the respondent's knowledge, attitude and practice regarding different aspects of using ICT in teaching \& learning. and

- To find out the background factors that might be associated with KAP differences among respondents.

\section{Methodology}

The data for this study was collected in questionnaire method from a total of 523 respondents consists of 120 teachers \& 405 students selected randomly from different universities (both public \& private) in Dhaka city. The population of the study was all the tertiary level teachers and students in Dhaka Metropolitan City. Total 31 universities were considered for this study including 4 public universities and 27 private universities. The collected data was stored, summarized and analyzed using SPSS software. Univariate frequency distribution method, bivariate crosstabs \& Chisquare test, Cramer's V \& Kendall's tau-b statistics were used to analyze the data.

\section{Findings}

Among 523 respondents, about $71 \%$ are male and $29 \%$ are female. About $78 \%$ of the respondents are from private universities and $22 \%$ are from public universities where $77 \%$ are students and $23 \%$ are teachers. Near $87 \%$ of the respondents have PC (either desktop or laptop) and 78\% respondents have regular personal internet connectivity and only about $1 \%$ has no internet connectivity, others have some few to moderate personal internet connectivity.

The findings of this study are organized in two sections; while first section focuses on the present situation of Knowledge, Attitude \& Practices (KAP) regarding different aspects of using ICT in teaching \& learning and their mutual associations, second section focuses on the associations of the background variables with the KAP variables. Frequency distribution tables are omitted for simplicity.

It has been found that, $93.7 \%$ of the respondents (whether teacher or student) know ICT can be used in teaching \& learning, $87 \%$ respondents believe ICT as a tool in teaching $\&$ learning and $53.8 \%$ respondents regularly uses ICT in teaching and learning. Table 1 illustrates the associations between the KAP variables on use of ICT as a tool in teaching \& learning. A weak positive but not significant $\left(\tau_{\mathrm{b}}=\right.$ $0.105, \mathrm{p}=0.070)$ relationship between knowledge $(\mathrm{K})$ and belief (A) about ICT use as a tool in teaching and learning can be seen from the table. Moreover, there is a very weak positive relationship between knowledge $(\mathrm{K})$ and practice $(\mathrm{P})$ about ICT usages as tools $\left(\tau_{\mathrm{b}}=0.099, \mathrm{p}=0.030\right)$. The practice level increased with the increase in knowledge. A significant, but weak positive relationship between belief and practice on ICT's usages as tools has also been found. $\left(\tau_{\mathrm{b}}=0.185, \mathrm{p}=\right.$ 0.000). Participants with positive attitude have showed a higher rate of practice of ICT in teaching \& learning.

\section{Volume 4 Issue 12, December 2015}




\section{International Journal of Science and Research (IJSR) \\ ISSN (Online): 2319-7064}

Index Copernicus Value (2013): 6.14 | Impact Factor (2014): 5.611

Table 1: KAP association on use of ICT as a tool in teaching and learning

\begin{tabular}{|c|c|c|}
\hline & $\begin{array}{c}\text { Respondent believes to } \\
\text { use ICT as a tool in } \\
\text { teaching and learning } \\
(A)\end{array}$ & $\begin{array}{c}\text { Respondent practices } \\
\text { ICT in his teaching } \\
\text { and learning }(P)\end{array}$ \\
\hline $\begin{array}{c}\text { Respondent knows } \\
\text { ICT can be used in } \\
\text { teaching \& learning } \\
(K)\end{array}$ & $\begin{array}{c}\text { Kendalles tau-b: } 0.105 \\
\text { p-value: } 0.070\end{array}$ & $\begin{array}{c}\text { Kendalles tau-b: } \\
0.099 \\
\text { p-value: } 0.030\end{array}$ \\
\hline $\begin{array}{c}\text { Respondent believes } \\
\text { to use ICT as a tool in } \\
\text { teaching and learning } \\
(A)\end{array}$ & - & $\begin{array}{c}\text { Kendallees tau-b: } \\
0.185\end{array}$ \\
\hline
\end{tabular}

Table 2: KAP association on use of Personal Email ID

\begin{tabular}{|c|c|c|}
\hline & $\begin{array}{c}\text { Respondent thinks } \\
\text { Personal Email ID } \\
\text { is essential for } \\
\text { today's } \\
\text { communication }(A)\end{array}$ & $\begin{array}{l}\text { Respondent } \\
\text { has personal } \\
\text { email ID and } \\
\text { he uses it. } \\
(P)\end{array}$ \\
\hline $\begin{array}{l}\text { Respondent knows } \\
\text { about use of Email ID } \\
\text { (K) }\end{array}$ & $\begin{array}{c}\text { Kendalle's tau-b: } \\
0.287 \\
\text { p-value: } 0.000\end{array}$ & $\begin{array}{c}\text { Crameres V: } \\
0.509 \\
\text { p-value: } \\
0.000\end{array}$ \\
\hline $\begin{array}{l}\text { Respondent thinks } \\
\text { Personal Email ID is } \\
\text { essential for today's } \\
\text { communication (A) }\end{array}$ & - & $\begin{array}{c}\text { Crameres V: } \\
0.325 \\
\text { p-value: } \\
0.000\end{array}$ \\
\hline
\end{tabular}

About 91\% respondents know about use of e-mail ID, $85 \%$ respondents think that personal email ID is essential for today's communication and $95.4 \%$ of the respondents have personal email ID and they use it. The knowledge about email ID and attitude towards using email ID has a significant and moderate positive association between them $\left(\tau_{\mathrm{b}}=0.287, \mathrm{p}=0.000\right)$. Participants with higher knowledge have showed more positive attitude. There are strong positive and significant associations identified between respondent's knowledge about use of email ID and the actual uses (Cramer's $\mathrm{V}=0.509, \mathrm{p}=0.000$ ) and between respondents ${ }^{\text {ee }}$ attitude towards using email ID and the actual uses (Crameres $\mathrm{V}=0.325, \mathrm{p}=0.000$ ) (table 2). Participants with positive knowledge \& attitude had higher usage of email ID.
Table 3: KAP association on use of Social Networks in teaching and learning

\begin{tabular}{|c|c|c|}
\hline & $\begin{array}{c}\text { Respondent thinks } \\
\text { Social Networks can be } \\
\text { used as a media of } \\
\text { teaching and learning } \\
(A)\end{array}$ & $\begin{array}{c}\text { Respondent uses } \\
\text { Facebook, twitter etc. } \\
\text { in his teaching and } \\
\text { learning }(P)\end{array}$ \\
\hline $\begin{array}{c}\text { Respondent knows } \\
\text { about social } \\
\text { networking and } \\
\text { social networks }(K)\end{array}$ & $\begin{array}{c}\text { Kendall'es tau-b: } 0.194 \\
\text { p-value: } 0.000\end{array}$ & $\begin{array}{c}\text { Kendalle's tau-b: } \\
\text { Respondent thinks } \\
\text { Social Networks can } \\
\text { be used as a media } \\
\text { of teaching and } \\
\text { learning }(A)\end{array}$ \\
\hline
\end{tabular}

Near $80.6 \%$ respondents know about social networking, $76 \%$ respondents think that social networks can be used as a media of teaching \& learning and $65.8 \%$ of the respondents regularly use Facebook, twitter etc. in teaching and learning. The study reveals a weak positive and significant relationship between respondent's knowledge about social networks and their attitude of using it as a media of teaching \& learning $\left(\tau_{\mathrm{b}}=0.194, \mathrm{p}=0.000\right)$. Higher knowledge has been found to be associated with positive attitude. The association between respondents ${ }^{\text {ee }}$ knowledge on social networking and their usage has been found to be moderate positive and significant $\left(\tau_{\mathrm{b}}=0.260, \mathrm{p}=0.000\right)$. Though some inconsistencies of responses have been found, respondents with higher knowledge have showed a higher level of usage. Respondents ${ }^{\text {ee }}$ attitude towards using social network as a teaching and learning media and the uses of various social networks by them shows similar type of association $\left(\tau_{\mathrm{b}}=\right.$ $0.210, \mathrm{p}=0.000)$ (table 3$)$.

Table 4: KP association on use of Multimedia Projector and Internet Access in classrooms

\begin{tabular}{|c|c|}
\hline & $\begin{array}{c}\text { Respondent uses Multimedia } \\
\text { Projector and Internet Access } \\
\text { in classrooms }(P)\end{array}$ \\
\hline $\begin{array}{c}\text { Respondent knows his } \\
\text { university has Multimedia } \\
\text { Projector and Internet }\end{array}$ & $\begin{array}{c}\text { Kendalle's tau-b: } 0.395 \\
\text { Access in classrooms }(K)\end{array}$ \\
\hline
\end{tabular}

About $77.6 \%$ of the respondents know that their university has Multimedia Projector and Internet Access in classrooms. $68.4 \%$ of the respondents reported that multimedia and internet facility is regularly used in classrooms. A strong positive \& significant association between the knowledge about Multimedia Projector and Internet accessibility in classrooms and actual use of those facilities $\left(\tau_{\mathrm{b}}=0.395, \mathrm{p}=\right.$ 0.000 ) (table 4). Respondent with higher knowledge about the facilities uses them more frequently. 


\section{International Journal of Science and Research (IJSR) \\ ISSN (Online): 2319-7064}

Index Copernicus Value (2013): 6.14 | Impact Factor (2014): 5.611

Table 5: KAP association on use of MS Office (MS Word, MS Excel and MS PowerPoint)

\begin{tabular}{|c|c|c|}
\hline & $\begin{array}{c}\text { Respondent feels comfortable to do task } \\
\text { by MS Word (A) }\end{array}$ & $\begin{array}{c}\text { Respondent does assignments and projects in MS } \\
\text { Word or uses MS Word etc. in teaching and } \\
\text { learning }(P)\end{array}$ \\
\hline $\begin{array}{l}\text { Respondent knows the functions of } \\
\text { MS Word (K) }\end{array}$ & $\begin{array}{c}\text { Kendalles tau-b: } 0.222 \\
\text { p-value: } 0.000\end{array}$ & $\begin{array}{c}\text { Kendalles tau-b: } 0.337 \\
\text { p-value: } 0.000\end{array}$ \\
\hline $\begin{array}{c}\text { Respondent feels comfortable to do } \\
\text { task by MS Word }(A)\end{array}$ & - & $\begin{array}{l}\text { Kendalle's tau-b: } 0.270 \\
\text { p-value: } 0.000\end{array}$ \\
\hline & $\begin{array}{c}\text { Respondent thinks MS Excel can make } \\
\text { task easy }(A)\end{array}$ & $\begin{array}{c}\text { Respondent uses MS Excel in teaching and } \\
\text { learning }(P)\end{array}$ \\
\hline $\begin{array}{l}\text { Respondent knows the functions of } \\
\text { MS Excel (K) }\end{array}$ & $\begin{array}{l}\text { Kendall }{ }^{\text {ee }} \text { s tau-b: } 0.192 \\
\text { p-value: } 0.000\end{array}$ & $\begin{array}{l}\text { Kendallees tau-b: } 0.273 \\
\text { p-value: } 0.000\end{array}$ \\
\hline $\begin{array}{c}\text { Respondent thinks MS Excel can } \\
\text { make task easy }(A)\end{array}$ & - & $\begin{array}{l}\text { Kendalles tau-b: } 0.248 \\
\text { p-value: } 0.000\end{array}$ \\
\hline & $\begin{array}{l}\text { Respondent thinks PowerPoint makes } \\
\text { presentation trouble-free }(A)\end{array}$ & Respondent uses MS PowerPoint for class $(P)$ \\
\hline $\begin{array}{l}\text { Respondent knows the functions of } \\
\text { MS PowerPoint }(K)\end{array}$ & $\begin{array}{c}\text { Kendalles stau-b: } 0.081 \\
\text { p-value: } 0.069\end{array}$ & $\begin{array}{l}\text { Kendalles tau-b: } 0.277 \\
\text { p-value: } 0.000\end{array}$ \\
\hline $\begin{array}{l}\text { Respondent thinks PowerPoint makes } \\
\text { presentation trouble-free }(A)\end{array}$ & - & $\begin{array}{l}\text { Kendall's tau-b: } 0.140 \\
\text { p-value: } 0.001\end{array}$ \\
\hline
\end{tabular}

It has been found that regarding the application of MS Office packages, $82.3 \%$ respondents know the function of MS Word well, $77.8 \%$ of the respondents feel comfortable to do task by MS Word and $65.3 \%$ of the respondents regularly use MS Word in teaching and learning. Whereas, $66.3 \%$ respondents know the function of MS Excel well, 72.3\% respondents think MS Excel can make our task easy but $47.7 \%$ respondents use MS Excel in teaching and learning. About 77\% respondents know about MS PowerPoint, 77\% respondents think MS PowerPoint makes our presentation trouble-free and $57.8 \%$ of the respondents use MS PowerPoint for classes.

Table 5 shows that, there has been a significant association, found between knowledge and attitude about using MS Word in teaching \& learning among students and teachers $\left(\tau_{\mathrm{b}}=\right.$ $0.222, p=0.000$ ). But the relationship is moderately positive. The level of attitude is moderately higher for those having higher knowledge. There is also a significant relationship between knowledge about MS Word and its uses in teaching $\&$ learning $\left(\tau_{\mathrm{b}}=0.337, \mathrm{p}=0.000\right)$. Respondents with higher knowledge on MS Word tend to use it more frequently. Attitude towards using MS Word \& actually using it associates moderately with each other $\left(\tau_{\mathrm{b}}=0.270, \mathrm{p}=0.000\right)$. Respondents with positive attitudes have showed slightly higher frequency of uses pattern than the others. Many of the respondents who don't feel comfortable to use MS Word, still uses it in teaching \& learning (58.3\%).

There is a significant, but weak association between the knowledge \& attitude towards using MS Excel $\left(\tau_{\mathrm{b}}=0.192\right.$, $\mathrm{p}=0.000$ ). Many respondents with no functional knowledge on MS Excel have showed positive attitude about using it and this percentage is slightly higher for those who have functional knowledge on it. There is a moderate positive \& significant association between knowledge on MS Excel \& its actual uses $\left(\tau_{\mathrm{b}}=0.273, \mathrm{p}=0.000\right)$. Respondents having a higher functional knowledge on MS Excel use it more regularly. There is also a significant association between the attitude and practice on using MS Excel $\left(\tau_{b}=0.248, p=\right.$ $0.000)$. The association is moderately positive. Respondents with positive attitude have a higher level of uses of MS Excel.

This study has found no significant association between the knowledge and attitude towards using MS PowerPoint $\left(\tau_{\mathrm{b}}=\right.$ $0.081, p=0.069$ ). Irrespective of the knowledge, most of the respondents think that PowerPoint makes presentation trouble-free. Significant associations have also been found from knowledge on \& attitude to MS PowerPoint with its uses by the respondents $\left(\tau_{\mathrm{b}}=0.277, \mathrm{p}=0.000 \& \tau_{\mathrm{b}}=0.140, \mathrm{p}=\right.$ 0.001 respectively). A higher usage frequency has been identified among respondents having more functional knowledge on MS PowerPoint. Respondents with positive attitude towards using PowerPoint use PowerPoint a bit more frequently.

Table 6: KA association on use of E-learning services

\begin{tabular}{|c|c|}
\hline & $\begin{array}{c}\text { Respondent thinks E-learning helps us to } \\
\text { learn without school }(A)\end{array}$ \\
\hline $\begin{array}{c}\text { Respondent knows } \\
\text { about online } \\
\text { educational services } \\
(\mathrm{K})\end{array}$ & $\begin{array}{c}\text { Kendalle's tau-b: } 0.206 \\
\text { p-value: } 0.000\end{array}$ \\
\hline
\end{tabular}

About $66 \%$ respondents have said that they know about online course services. About $54 \%$ of the respondents think that e-learning helps to learn without school. Respondents who have higher knowledge on online educational services agree more with that ,e-learning helps to learn without school $^{\text {ee }}$ and the association between them is significant $\left(\tau_{\mathrm{b}}=\right.$ $0.206, p=0.000)$ (table 6).

Table 7: KA association on use of web conferencing in teaching and learning

\begin{tabular}{|c|c|}
\hline & $\begin{array}{c}\text { Respondent thinks People can } \\
\text { learn and teach by web } \\
\text { conferencing method }(A)\end{array}$ \\
\hline $\begin{array}{c}\text { Respondent knows about web } \\
\text { conferencing in teaching and } \\
\text { learning }(K)\end{array}$ & $\begin{array}{c}\text { Kendallees tau-b: } 0.324 \\
\text { p-value: } 0.000\end{array}$ \\
\hline
\end{tabular}

\section{Volume 4 Issue 12, December 2015}




\section{International Journal of Science and Research (IJSR) \\ ISSN (Online): 2319-7064 \\ Index Copernicus Value (2013): 6.14 | Impact Factor (2014): 5.611}

About $67 \%$ respondents have said that they have idea or knowledge about web conferencing. On the other hand, about $69 \%$ of the respondents think people can learn and teach by web conferencing method. Respondents having higher knowledge about web conferencing method in teaching \& learning have showed higher percentage of positive attitude towards using as a teaching \& learning method $\left(\tau_{\mathrm{b}}=0.324, \mathrm{p}=0.000\right)$ (table 7$)$.

The associations of different background variables of respondents with their knowledge, attitude \& practices in different aspects of using ICT in teaching \& learning are discussed below. Only the associations that have showed statistical significance at most 5\% level of significance are provided in this section. The Chi-square test is applied for testing the associations.

There have been some significant differences found between teachers and students regarding the knowledge on usage of ICT in teaching and learning, on usage of email ID, on the functions of MS Word, Excel and PowerPoint, about online course services, about web conferencing in teaching and learning. A higher percentage of teachers has knowledge on above matters than students. This type of significant differences also prevalent between participants from private and public university regarding the knowledge about use of email ID, on the functions of MS Word, Excel and PowerPoint, about online courses and about web conferencing in teaching and learning. A higher percentage of respondents from private universities has knowledge on this matters than the respondents from public universities. There are also some significant differences between the participants who have $\mathrm{PC}$ and who don't regarding knowledge about the functions of MS Word, Excel and PowerPoint, about online courses, and about web conferencing in teaching \& learning. Percentages of the respondents who have $\mathrm{PC}$ are higher concerning these knowledge than the respondents who don't have PC.

In terms of attitude, there are significant differences between teachers and students regarding attitude towards e-learning resources, using ICT in Teaching \& learning and using MS Word to do tasks. A higher percentage of teachers has positive attitude towards above mentioned matters than students.

It has also been found that, there are significant differences in the percentages among respondents having different level of internet connectivity regarding using personal email ID, using MS Word, Excel and PowerPoint, using ICT in teaching and learning, using Facebook, twitter etc. in teaching \& learning, using ICT in educational purpose, using multimedia projector in classrooms. The usage has showed increasing percentages as the internet connectivity level increases. Significant differences are also prevalent between teachers and students in the frequency of uses of MS Word and PowerPoint, uses of ICT in teaching and learning, uses of ICT in educational purpose. Teachers have higher frequency in those practices. The percentages of the use of MS Excel in teaching and learning are significantly higher for males than females. Some significant differences also identified between respondents from public and private universities regarding the use of MS Word, PowerPoint, and use of ICT services in educational purpose. Respondents from private universities have higher frequency of usage than the respondents from public universities regarding the above mentioned ICT facilities. There are also some significant differences between the respondents who have PC and who haven 't regarding use of MS Word, Excel and PowerPoint, use of ICT in teaching and learning, use of ICT services for educational purpose, use of multimedia projector in classrooms. Respondent who has PC shows a higher frequency of usage regarding above facilities than the respondents who do not have $\mathrm{PC}$.

\section{Discussions}

Present situational analyses of Knowledge, Attitude \& Practice (KAP) regarding different ICT tools \& services viz.emailing, using social networks, using Office packages (here, MS Office, since this is the commonly used office package in Bangladesh), multimedia projector, e-learning \& web conferencing; and their relationship between themselves \& with the background characteristics viz.- gender, occupation (student/ teacher), university type, possession of PC \& internet connectivity are identified in this paper.

Percentages of knowledges of different ICT tools \& services are higher than the attitudes towards using those, which are also higher than the practices (i.e. actual use) for most of the cases, except the use of MS Excel \& web conferencing, where attitudes show higher percentages than knowledges. That is, in those particular cases, respondents feel positive to use those tools, but do not have enough knowledge to actually use those.

Knowledge, Attitude \& Practice regarding uses of ICT tools $\&$ services have been found to be related with each other \& with different background characteristics of the respondents (teachers \& students) significantly. In some cases (using PowerPoint, Excel \& social networks), it has been found that knowledge \& attitude were not related significantly with each other or very weakly related to each other, but among all the cases knowledge \& attitude have been found to be significantly related with practice and in most of the cases \& those associations were moderate to strong positive.

Knowledge about the function of MS Word, Excel and PowerPoint, about online resources, and about web conferencing have been found to be associated with or differed by occupation, university type and ownership of PC. On the other hand, attitude towards e-learning resources, using ICT in Teaching \& learning and using MS Word to do tasks have only been found associated with occupation. Finally, usage of MS Word and PowerPoint, application of ICT in teaching and learning, and in educational purpose, usage of university email ID, website and e-learning resources commonly have been found to be associated with internet connectivity, occupation, gender, university type and ownership of PC.

By comparing the above discussions, it can be said that occupation, university type and ownership of PC are the three common factors which are associated with differences within the most of the KAP variables. This gives a slightly different outcomes (in Bangladesh) with the study (in 


\section{International Journal of Science and Research (IJSR) \\ ISSN (Online): 2319-7064 \\ Index Copernicus Value (2013): 6.14 | Impact Factor (2014): 5.611}

Nigeria) "Student-Teachers" Competence and Attitude towards Information and Communication Technology: A Case Study in a Nigerian University" (Yusuf \& Balogun, 2011) [7] as that study found no significant difference between male and female student-teachers ${ }^{e e}$ attitudes and use of ICT.

\section{Conclusion}

It has been observed that when persons have more knowledge, then they practice more and attitude also get shaped. The study revealed that $\mathrm{K}, \mathrm{A}$ and $\mathrm{P}$ are interlinked in all the aspects. Moreover, when people have positive attitude towards using ICT in education, they are interested to practice more though they might not have sufficient knowledge. People who are using ICT in their teaching and learning more, they either have knowledge or have positive attitude. Practicing or Integrating ICT in education ensures quality and active learning. A positive attitude towards the use of ICT correlates with level of ICT use and vise-visa which should be our greater concern (Al-Zaidiyeen, Mei, \& Fook, May 2010) [8]. Successful ICT implementation in teaching and learning requires using ICT in line with educational goal, having knowledge and awareness of ICT based education system (Alharabi, 2014) [9]. To establish effective ICT based education, Knowlede , Attitude and Practice of ICT use are equally imperative. Further study can explore indetails findings about ICT integration in education, how ICT implementation could be more effective etc.

\section{References}

[1] B. Cubukcuoglu, "Factors enabling the use of technology in subject teaching," International Journal of Education and Development using Information and Communication Technology , pp. 50-60, 2013

[2] S. Goharinezhad, Z. Faraji, \& B. Jameie, "Knowledge, Attitude and Practice (KAP) Study of Faculty Members on Integrated Digital Library (IDL) in Tehran University of Medical Sciences," International Journal of Digital Library Services , pp. 51-62, 2012

[3] M. S. Rahman, \& N. Akter, "ICT-Periodism in the Classroom: Lessons Learnt from English in Action," International Journal of Science and Research (IJSR), pp. 1330-1334, 2015.

[4] K. A. Bingimlas, "Barriers to the Successful Integration of ICT in Teaching and Learning Environments: A Review of the Literature," Eurasia Journal of Mathematics, Science and Technology Education, pp. 235-245, 2009.

[5] P. Ndibalema, "Teachers"e Attitudes towards the Use of Information Communication Technology (ICT) as a Pedagogical Tool in Secondary Schools in Tanzania: The Case of Kondoa District," International Journal of Education and Research , pp. 1-16, 2014.

[6] P. A. Ertmer, A. T. Ottenbreit-Leftwich, O. Sadik, E. Sendurur, \& P. Sendurur, "Teacher beliefs and technology integration practices: A critical relationship," Computers \& Education , pp. 423-435, 2012

[7] M. O. Yusuf, \& M. R. Balogun, "Student-Teachers Competence and Attitude towards Information and Communication Technology: A Case Study in a Nigerian
University," Contemporary Educational Technology, pp. 18-36, 2011.

[8] N. J. Al-Zaidiyeen, L. L. Mei, \& F. S. Fook, "Teachers"e Attitudes and Levels of Technology Use in Classrooms:The Case of Jordan Schools," International Education Studies, Vol. 3, No. 2, pp. 211-218, 2010.

[9] H. E. Alharabi, "Towards successful implementation of ict in education," In Proceedings of The 2014 WEI International Academic Conference, pp. 33-45, Vienna, Austria: The West East Institute, 2014

\section{Author Profile}

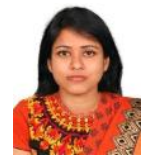

Arifa Rahman received her Master of Education from Institute of Education and Research, University of Dhaka, Bangladesh in 2010; the Bachelor of Education from the same institute in 2008. She is going to pursue her $2^{\text {nd }}$ Master on Special Education with an Endeavour Scholarship. She was a teaching assistant, lecturer, lecturer II with BRAC Institute of Languages, BRAC University in 2010, 2011 and 2012 respectively. She has been working as Asst. Professor and lead facilitator at Green University Center of Excellence for Teaching and Learning, Green University of Bangladesh. Her research interests include teaching \& learning, technology based education, moral education and ethics teaching, social media and education, emotional intelligence, psychological issues and learning, special education and technology based education.

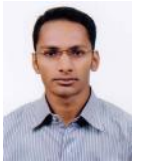

F. M. Arifur Rahman received his B.S. and M.S. degree in Statistics from University of Dhaka, Dhaka, Bangladesh, in 2012 and 2014 respectively. He was a teaching assistant at Department of Applied Statistics, East West University, Dhaka, Bangladesh, in 2014. He has been working as a lecturer at Center for Research, Innovation \& transformation, Green University of Bangladesh. His research interests include Artificial Intelligence, ICT and Education. 